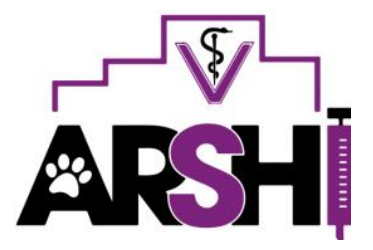

Veterinary Letters

ISSN 2581-2416

DOI: http://dx.doi.org/10.29244/avl.2.2.21-22

http://journal.ipb.ac.id/index.php/arshivetlett

\title{
Urolithiasis oksalat monohidrat pada kucing lokal
}

\author{
Iwan Harjono Utama*, Sri Kayati Widyastuti, I Gusti Made Krisna Erawan, Ekklesia Prasetya \\ Fakultas Kedokteran Hewan, Universitas Udayana, Denpasar, Bali
}

\begin{abstract}
ABSTRAK: Kasus urolithiasis oksalat monohidrat dijumpai pada kucing lokal yang datang ke Rumah sakit Hewan Fakultas Kedokteran Hewan Universitas Udayana dengan anamesis kucing mengalami penurunan nafsu makan. Gejala klinis yang terlihat adanya kifosis ringan. Palpasi di abdomen bagian atas hingga belakang dilakukan dan hewan meronta kesakitan saat palpasi di bagian hypogastrium medial vesica urinaria. Kucing juga menunjukkan ekspresi nyeri saat dilakukan palpasi pada bagian penis saat pemeriksaan uretra dan urinasi. Kucing sedikit-sedikit mengeluarkan urin berdarah dengan konsistensi cair. Pemeriksaan lanjut dilakukan menggunakan ultrasonografi dan urinalisis menggunakan uji cepat dipstik. Hasil pemeriksaan ultrasonografi memperlihatkan adanya bintik bintik putih di vesika urinaria, sedangkan pemeriksaan fisik urin memperlihatkan hematuria dan mikroskopik memperlihatkan adanya kristal oksalat monohidrat. Penanganan yang dilakukan pada kasus ini adalah memberikan antibiotik amoxicillin injeksi dosis $11-22 \mathrm{mg} / \mathrm{kg}$ bb untuk mengurangi infeksi pada saluran kemih. Selain itu Nephrolit@ yang mengandung Orthosiphon stamineus (kumis kucing) dan beberapa herbal lainnya juga diberikan untuk membantu alkalinisasi dan pelarutan kristal-kristal dalam urin agar mudah dikeluarkan saat urinasi. Hasil penanganan memperlihatkan kucing membaik dalam waktu 10 hari terapi.
\end{abstract}

Kata kunci:

oksalat monohidrat, kucing, urinalisis

\section{- PENDAHULUAN}

Kasus urolithiasis merupakan kejadian penyakit yang sangat umum pada hewan kesayangan, terutama kucing. Laporan Rumah Sakit Hewan (RSH) Universitas Udayana, kasus urolithiasis hampir selalu ada setiap bulannya, bahkan hingga terjadi beberapa kasus baik pada anjing maupun kucing. Kasus urolithiasis pada kucing jantan yang terekam pada bulan Januari 2017 dilaporkan sebanyak 4 kasus.

\section{- KASUS}

Seekor kucing jantan ras Persia datang ke Rumah Sakit Hewan Fakultas Kedokteran Hewan Universitas Udayana. Anamnesis: Kucing persia dipelihara sejak lahir bersama induknya sampai saat ini berumur satu tahun. Pemilik memiliki dua kucing yang terdiri dari satu anak dan satu induk. Nafsu makan mulai menurun sejak dua hari yang lalu, pakan diberikan dua kali sehari pagi dan sore selalu habis, akan tetapi sejak 2 hari belakangan makanan selalu bersisa. Gejala dan pemeriksaan klinis: Kucing memperlihatkan gejala kifosis ringan, saat dipalpasi di abdomen bagian atas-belakang tidak memerlihatkan respon berontak atau kesakitan. Hewan memerlihatkan gejala lemas dan muntah berbusa dengan suhu rektal masih 37.3 ${ }^{\circ} \mathrm{C}$. Rasa sakit jelas tampak saat dilakukan palpasi di bagian hypogastrium medial vesika urinaria. Ekspresi nyeri saat dilakukan palpasi pada bagian penis untuk memeriksa keadaan uretra. Alat kelamin juga sedikit-sedikit mengeluarkan kencing berdarah dengan konsistensi cair (Gambar 1a). Pemeriksaan lanjutan pada kantung urin dilakukan menggunakan alat ultrasonografi (Mindray- 1200 Vet ${ }^{\circledR}$, China). Analisis urin dilakukan menggunakan dipstik (Nova ${ }^{\circledR}$, Canada) dan konfirmasi mikroskopik dilakukan untuk melihat jenis kristal dan keberadaan sel dalam urin.

\section{- HASIL}

Pemeriksaan fisik urin memperlihatkan hematuria (Gambar 1a). Songoram tampak bintik putih hiperekhoik dalam vesika urinaria (Gambar 1b). Sendimentasi urin tampak ada endapan (Gambar 2a). Citra mikroskopik memperlihatkan kristal oksalat monohidrat dan eritrosituria (Gambar 2b). Tabel 1 menunjukkan hasil pemeriksaan laboratorium.
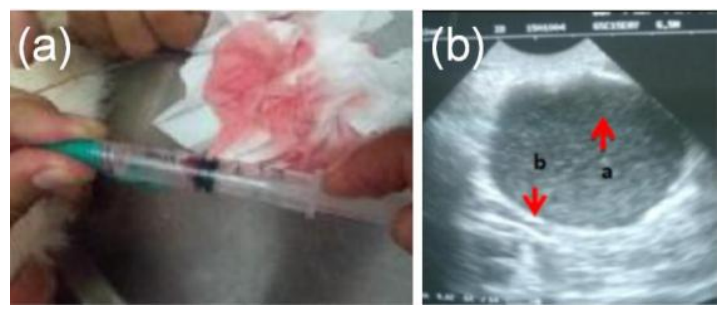

Gambar 1. (a) Kateterisasi urin berwarna merah dan (b) sonogram kantung kemih tampak citra pasir hiperekoik (panah a dan b).

Diterima: 07-01-2018 | Direvisi: 21-01-2018 | Disetujui: 08-02-2018 (C) 2018 CC-BY-SA. Ini adalah artikel Open Access yang didistribusikan berdasarkan ketentuan dari Creative Commons Attribution ShareAlike 4.0 International License (https://creativecommons.org/licenses/by-sa/4.0/). 

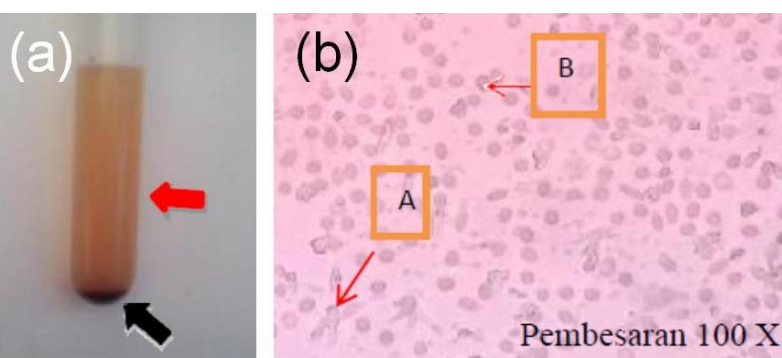

Gambar 2. (a) Hasil sedimentasi urin keruh berwarna merah (panah merah) dengan adanya endapan (panah hitam) dan (b) pemeriksaan mikroskopik terlihat adanya banyak sel darah merah (panah A) dan ditemukan bentukan kristal (panah B).

Tabel 1 Gambaran fisik dan hasil pemeriksaan laboratorium urin kucing penderita urolithiasis oksalat monohidrat.

\begin{tabular}{|l|l|l|}
\hline Parameter & Hasil & Normal \\
\hline Warna & Merah & Kuining terang \\
Kejernihan & Keruh & Jernih \\
$\mathrm{Bau}$ & Pesing dan amis & Pesing \\
$\mathrm{pH}$ & 6,5 & $6,0-7,0$ \\
Berat jenis & 1,030 & $1,020-1,040$ \\
Leukosit & $++(75 / \mu \mathrm{L})$ & - \\
Nitrit & - & - \\
Protein & $+(25 \mathrm{mg} / \mathrm{dL})$ & - \\
Glukosa & - & - \\
Keton & - & - \\
Urobilinogen & - & - \\
Bilirubin & - & - \\
Eritosit & $+++(200 / \mu \mathrm{L})$ & - \\
\hline
\end{tabular}

\section{- PEMBAHASAN}

Urolithiasis merupakan pernyataan umum dari keberadaan batu di saluran perkencingan yang perlu ditelaah lebih lanjut mengenai jenis batu/ kristal yang membentuknya (Gregory 2014). Dari data kasus ini (termasuk laboratorium), dapat didignosa bahwa kucing menderita urolithiasis oksalat monohidrat, selain itu adanya leukouria mengindikasikan infeksi di vesica urinaria atau saluran kencing (Tabel 1). Citra ultrasonografi memerlihatkan tampilan hiperekoik pada kristal yang terkandung didalam urin (Tion et al. 2015). Adanya proteinuria dan eritrosituria juga memperlihatkan dampak kristal oksalat monohidrat terhadap saluran urinaria bagian bawah yang sesuai dengan pendapat Okafor et al. (2013). Keberadaan kristal ini bisa disebabkan oleh berbagai faktor seperti keasaman $\mathrm{pH}$ urin yang terus menerus (Gisselman et al. 2009). Pada kucing, jika hal ini mencapai angka 10 dapat memicu pembentukan kalsium oksalat (Bartges 2017; Evason et al. 2016). Selain itu, adanya oksalat monohidrat dapat disebabkan pakan yang berpotensi mengasamkan urin (Gauer 2014) atau merupakan salah satu dampak samping dalam usaha menekan pembentukan struvite (Ross 2005).

Penanganan yang dilakukan pada kasus ini adalah memberikan antibiotik amoxicillin (Betamox LA, PT Perkasa Veterinaria, Indonesia) diinjeksikan $0.3 \mathrm{~mL}$ dengan dosis 11-22 mg/kg bb. Pemberian antibiotik digunakan untuk mengurangi infeksi pada saluran kemih. Sedangkan Nephrolit ${ }^{\circledR}$ (PT Bintang Toedjoe, Indonesia) mengandung Orthosiphon stamineus, Strobilantus crispus, Sonchus arvensis dan Phyllanthus niruri yang berfungsi membantu alkalinisasi urin dan pelarutan kristal-kristal di urine agar mudah dikeluarkan saat urinasi (medical dissolution) (Tion et al. 2015). Hal ini sebagaimana yang telah dijelaskan oleh Bowles (2008). Kucing mengalami kesembuhan setelah 10 hari penanganan. Walaupun terapi menggunakan sediaan herbal berhasil dengan baik pada kucing, akan tetapi hewan tetap harus diberi minum secara ad libitum (client education) dan urinasi harus dicermati pascaterapi.

\section{口 SIMPULAN}

Penanganan kasus urolithiasis akibat oksalat monohidrat dapat dilakukan dengan pemberian antibiotik amoxicillin dan herbal Orthosiphon stamineus memberi hasil yang baik.

\section{- INFORMASI PENULIS}

Penulis untuk Korespondensi

*IHU: iwanhu2006@gmail.com

Fakultas Kedokteran Hewan, Universitas Udayana,

Jalan P.B. Sudirman, telp- fax : 0361223791 Denpasar, Bali

\section{- PUSTAKA ACUAN}

Bartges J. 2017. Urinary saturation and urolithiasis. http://www.vet.dev.adverteaser.com/convegno/URINARYSATURATION-AND-UROLITHIASIS.pdf

Bowles M. 2008. Stalking stones: An overview of canine and feline urolithiasis. http://veterinarymedicine.dvm360.com/ stalking-stones-overview-canine-and-feline-urolithiasis

Evason M, Remillard R, Bartges J. 2016. ASK Understanding urinary relative supersaturation. April 2016. pp 24-28 http://www.cliniciansbrief.com/sites/default/files/attachments/ ASK_Understanding\%20Urinary\%20Relative\%20Supersaturat ion.pdf

Gauer GF. 2014. Calcium oxalate urolithiasis. October 2014. pp 51-55. http://www.cliniciansbrief.com/sites/default/files/ attachments/Calcium\%200xalate\%20Urolithiasis.pdf

Gisselman K, Langston C, Palma D. Mc Cue J. 2009. Calcium oxalate urolithiasis. Compendium: Continuing education for veterinarians. November 2009: 496-502. http://vetfoliovetstreet.s3.amazonaws.com/mmah/ee/39483080544657a3bdc a81f7d13abe/filePV_31_11_496.pdf

Gregory FG. 2014 Prevalence of urinary calculi in dogs \& cats http://todaysveterinarypractice.navc.com/wp-content/uploads/ 2016/06/T1509C04.pdf

Okafor CC, Pearl DL, Lefebvre SL, Wang M, Yang M, Blois SL, Lund EM, Dewey CE. 2013. Risk factors associated with struvite urolithiasis in dogs evaluated at general care veterinary hospitals in the United States. J Am Vet Med Assoc. 243(12):1737-45

Ross LA. 2005. Calcium oxalate urolithiasis in dogs and cats. Standard of care: Emergency and critical care medicine. 7(7): 1-7.

Tion MT, Dvorska J, Saganuwan JA. 2015. A Review on urolithiasis in dogs and cats. Bulgarian J Vet Med. 18(1): 1-18. 